\title{
Medically unexplained pain is not caused by psychopathology
}

\author{
Lucia Gagliese $\mathrm{PhD}^{1}$, Joel Katz $\mathrm{PhD}^{1,2}$
}

\section{Gagliese, J Katz. \\ Medically unexplained pain is not caused by psychopathology. Pain Res Manage 2000:5(4):251-257.}

This paper highlights Professor Ronald Melzack's theoretical contributions to the understanding of psychological factors in pain. His work continues to have profound influences on pain theory, research, management and public policy. His ideas have been pivotal to the acceptance of the role of the brain and psychological factors in the experience of pain. This article briefly outlines the prevailing theories of the psychology of pain before the gate-control theory. Melzack's contributions argue against the simplistic linear thinking inherent in specificity theory, which leads to the attribution of pain to either 'organic' or 'psychogenic' causes. Nevertheless, Cartesian dualism continues to thrive. The authors illustrate the nature and extent to which dualistic thinking pervades the field, show that a dualistic conceptualization of pain introduces an element of distrust to the relationship between patient and health professional, and conclude that the available data fail to reach today's standards for an evidence-based approach to pain. The authors believe that medically unexplained pain is not a symptom of a psychological disorder and that it is time to abandon the thinking that separates mind and body. The challenge remains for proponents to provide the empirical evidence to prove that psychopathology causes pain and, in so doing, to specify the mechanisms by which it is generated.

Key Words: Medically unexplained pain; Orofacial pain; Psychogenic pain; Psychopathology

\section{La douleur que la médecine n'arrive pas à expliquer n'est pas forcément causée par une psychopathologie}

RÉSUMÉ : Cet article souligne les contributions théoriques du professeur Ronald Melzack à la compréhension des facteurs psychologiques de la douleur. Ses travaux continuent d'exercer une influence marquante sur la théorie, la recherche, le traitement et les politiques touchant la douleur et son traitement. Ses idées ont été au cœur de l'acceptation du rôle du cerveau et des facteurs psychologiques dans la sensation douloureuse. Cet article résume brièvement les théories qui avaient cours au sujet de la psychologie de la douleur avant l'avènement de a théorie du contrôle par soupapes de la douleur. Les contributions de Melzack vont à l'encontre d'une ligne de pensée simpliste inhérente à la théorie de la spécificité en vertu de laquelle on attribue la douleur soit à des causes organiques ou à des causes psychogéniques. Néanmoins, le dualisme cartésien continue de sévir. Les auteurs illustrent à quel point la nature et l'étendue de cette pensée dualiste conditionnent le domaine, démontrent qu'une conceptualisation dualiste de la douleur ouvre la porte à un élément de méfiance dans le rapport qui s'installe entre le patient et le professionnel de la santé et conclut que les données disponibles ne permettent pas l'atteinte des standards actuels pour une approche de la douleur fondée sur des preuves. Selon les auteurs, la douleur qui ne peut être expliquée par des raisons médicales n'est pas un symptôme d'une détresse psychologique et il est temps d'abandonner cette façon de penser qui sépare l'esprit du corps. Il reste désormais à fournir des preuves empiriques pour confirmer que la psychopathologie provoque la douleur et ce faisant de spécifier les mécanismes par lesquels naît la douleur.

\footnotetext{
${ }^{1}$ Acute Pain Research Unit, Department of Anaesthesia, Toronto General Hospital and Mount Sinai Hospital, and ${ }^{2}$ Department of Public Health Sciences and Department of Anaesthesia, University of Toronto, Toronto, Ontario

Correspondence: Dr J Katz, Acute Pain Research Unit, Department of Anaesthesia, Toronto General Hospital, 200 Elizabeth Street, CW 2-306, Toronto, Ontario M5G 2C4. Telephone 416-340-3777, fax 416-340-4739, e-mail joel.katz@uhn.on.ca
} 
It is unreasonable to ascribe chronic pain to neurotic symptoms. The patients with the thick hospital charts are all too often prey to the physician's innuendoes that they are neurotic and that their neuroses are the cause of the pain. While psychological processes contribute to pain, they are only part of the activity in a complex nervous system. All to often, the diagnosis of neurosis as the cause of pain hides our ignorance of many aspects of pain mechanisms. (1)

W e are truly honoured to be part of this tribute to Professor Ronald Melzack, who has played a pivotal role in our careers. We both had the good fortune to pursue doctoral research in clinical psychology at McGill University, Montreal, Quebec, under Ron's mentorship. This may be surprising to some readers, given that Ron is an experimental, not a clinical, psychologist. Nonetheless, his unique understanding of the role of psychological factors in pain and his unwavering empathy and compassion for the patients he encounters on a weekly basis at the McGill-Montreal General Hospital Pain Centre make him a most suitable experimental and clinical teacher. Our objective is to highlight Ron's theoretical contributions to the understanding of psychological factors in pain. Although much of his work argues against the simplistic linear thinking that attributes pain to either 'organic' or 'psychogenic' causes, we show that this unfortunate remnant of specificity theory persists. Further, we argue that this thinking is discordant with the empirical evidence, is of no clinical utility and should be abandoned.

Over the past 40 years, Ron has made major contributions that have had profound influences on pain theory, research, management and public policy. His ideas have been pivotal to the acceptance of the role of the brain and psychological factors in the experience of pain. He has long advocated the importance of these factors in pain (2), and in collaboration with Patrick Wall, developed the gate-control theory of pain (3), which explicitly integrates psychological and physiological processes in pain perception. This collaboration between a psychologist and physiologist, in and of itself, is a testament to Ron's pioneering spirit and vision regarding the need to approach the problem of pain from a multidisciplinary perspective that includes physiological, psychological, cultural and social influences. This is especially notable given that the theory was published more than a decade before Engel (4) introduced the biopsychosocial model to understand complex health-related phenomena.

Before the advent of the gate-control theory, the dominant view of pain was specificity theory, a dualistic, Cartesian concept of specialized 'pain receptors' that transmitted 'pain signals' along a 'pain pathway' to a 'pain centre' in the brain (5). According to this model, the brain was simply the passive recipient of messages from the periphery and did not actively modulate the experience of pain. Psychological factors were not considered primary, and what are now recognized as normal psychological sequelae of chronic pain were attributed to psychopathology (5).

Gate-control theory not only was able to account for much of the data that did not fit specificity theory but also explicitly acknowledged the role of psychological factors. Gate-control theory postulates that the experience of pain is influenced by multiple inputs, including primary afferent input, into the dorsal horns, as well as inhibitory and facilitatory messages descending from the brain (3). As such, the brain is actively involved in the generation and modulation of pain. Although this theory initially met with strong opposition, it is now widely accepted and is described in all the major textbooks of medicine, psychology and physiology (6).

In 1968, in collaboration with Kenneth Casey, Ron further refined his views regarding the role of the brain in pain. Melzack and Casey (7) proposed that pain is a multidimensional experience made up of sensory-discriminative, motivational-affective and evaluative dimensions, and that each of these dimensions is subserved by specialized interacting systems in the brain. This conceptualization has had a significant impact on the understanding of pain mechanisms and on pain management principles. It is now widely accepted that pain is a multidimensional experience.

A major advance of gate-control theory followed detailed observation of phantom body pain below the level of total transection of the spinal cord in paraplegics. Ron, in collaboration with John Loeser (8), suggested that the brain could generate pain even in the absence of a connection between it and the spinal cord. This means that the brain can create perceptual experience independent of peripheral input.

More recently, these ideas, coupled with other observations of phantom phenomena, have led Ron to propose a radical reconceptualization of the brain's role in the generation and modulation of perceptual experience, specifically neuromatrix theory $(6,9,10)$. The details of this are beyond the scope of the present paper. For our purposes, we focus only on two of the core conclusions upon which this theory is based. Specifically, that pain (and all perceptual experience) is the end product of an active brain creating subjective experience both in response to and (potentially) independent of sensory input. As such, the brain is critically involved in the generation of pain regardless of the extent of tissue damage or pathology. A second conclusion is that experience and sensory input continually modify the neuromatrix. The clinical implications of these postulates cannot be overemphasized. Put plainly, they reduce to absurdity the dichotomization of pain into 'organic' and 'psychogenic' etiologies. All pain is the end result of activity in the neuromatrix. Therefore, pain that cannot be easily linked to observable pathology or that has 'nonanatomical' characteristics is not evidence of psychopathology but rather is generated by the activity of the neuromatrix (11).

In summary, Ron's ideas continue to have a revolutionary impact on the conceptualization of psychological factors in pain. As a result of his work, it is no longer possible to argue for discrete 'organic' and 'psychogenic' etiologies of pain. Rather, all pain, from that associated with a stubbed toe to that of the most torturous neuropathy to that which arises spontaneously and without apparent tissue damage or pathology, is a multidimensional experience made up of a complex 
interaction of sensory, affective and cognitive components within the central nervous system (7). Within this framework, pain that arises from thoughts and feelings is normal and not an indication of psychopathology or psychiatric illness. To appreciate fully the impact of Ron's work, we briefly outline the prevailing ideas of the psychology of pain before gate-control theory and evaluate the current research in this area.

\section{THE ROLE OF PSYCHOLOGY BEFORE THE GATE-CONTROL THEORY}

The predominant view of the role of psychological factors in pain before the gate-control theory was that psychopathology caused medically unexplained pain (12-14). There was little recognition of the effects of chronic pain on psychological and emotional functioning (15). Psychopathology was invoked to explain pain that could not otherwise be understood on the basis of existing physiological and anatomical knowledge. This is a recurrent theme in the history of pain and medicine. The dualism inherent in these approaches led to an artificial distinction between 'organic' pain and 'psychogenic' pain. In the ensuing years, a variety of terms cropped up that reinforce this dichotomy (eg, psychogenic, functional, nonorganic, psychosomatic, idiopathic, atypical, medically unexplained), many of which persist to this day (16).

The practice of relegating certain inexplicable phenomena to the psychological or emotional realm may free the theorist from considering them further, but from a clinical perspective it is damaging to the patient. Labels such as 'psychogenic' change how the individual is viewed and treated, implicitly blame him or her for the pain, and provide nothing helpful in the way of managing the pain. It is crucial to differentiate legitimate attempts to explain how psychology influences pain experience from attempts to use a label as a selfserving explanation (17).

These early theories $(12,14)$ were serious attempts to account for baffling pain phenomena from a psychoanalytic perspective, but it is important to realize that they lack supporting empirical evidence and fail to reach today's standards for an evidence-based approach to pain. For example, Szasz (14) proposed that the normal, nonpainful phantom limb that develops after limb amputation represented an unconscious denial of the loss and that phantom limb pain arose from a denial of the affect associated with the loss. This elegant theory, however, is not tenable in light of recent developments in the understanding of the neurophysiology and psychology of pain (18). Later, Engel (12) introduced the concept of a 'pain prone patient' and popularized the use of the term 'psychogenic pain'. He proposed several mechanisms by which psychological processes were believed to cause chronic pain. These included the conversion of guilt, aggression or conflict over sexual impulses into pain. The pain then served the ego-protective function of ensuring that the conflict remained out of consciousness and at the same time as punishment and atonement for the unconscious impulses. The location of the pain was thought to be symbolic and determined by unconscious identification with an impor- tant person in the patient's life who had pain in a similar location or was thought by the patient to have had pain in that location. Alternately, the pain was considered to be similar to a past pain experienced by the patient during a conflict with the important person.

The terms 'pain prone' and 'psychogenic pain' (12) continue to be used with increasing regularity notwithstanding the absence of empirical data to support these concepts. Engels' (12) original paper recently has been reprinted in its entirety (19), providing further evidence of how 'excess baggage from previous decades' in the form of outdated ideas and terminology continue to influence current clinical practice and affect patients' lives (20).

\section{REMNANTS OF CARTESIAN DUALISM PERVADE CURRENT CONCEPTUALIZATIONS OF PAIN}
It is clear, then, that 'psychogenic pain' and 'organic pain'are not two kinds of pain in the sense in which English and French are two kinds of languages. Instead they resemble the expressions 'beautiful painting' and 'ugly painting'; these are judgments which an observer might render about different canvases, or which different observers might render about the same canvas. (21)

The theories that we hold shape our understanding and interpretation of the world. More practically, they determine our research agendas, study designs, data interpretation and clinical practice. This is as true in the study of pain as in any other field. The research and clinical practice that result from adhering to dualistic linear theories of pain are very different from those that are guided by the theoretical foundations laid down by Ron. Unfortunately, dualistic thinking continues to influence clinical research into many types of pain. Space limitations prevent us from exploring each of these in detail. Instead, we focus on the orofacial pain literature to illustrate the nature and extent to which dualistic thinking pervades the field, to show that a dualistic conceptualization of pain introduces an element of distrust into the relationship between patient and health professional, and to demonstrate that there is insufficient evidence to support continued adherence to this outdated mode of thinking.

Orofacial pain is defined as pain localized to the head, face, neck and intraoral structures $(22,23)$. The need for a multidimensional approach to the conceptualization of these disorders has been recognized by experts in chronic orofacial pain $(24,25)$, and Sessle (26), a leading basic scientist, has advocated the abandonment of specificity theory and the adoption of the gate-control theory as a conceptual framework. Nevertheless, a review of the literature in this field indicates that the dichotomy between organic and psychogenic pain continues to thrive. For instance, current textbooks of orofacial pain and recent reviews include discussions of the diagnosis and management of psychogenic pain, with emphasis on temporomandibular disorders, atypical facial pain and burning mouth syndrome (27-29). Furthermore, the recent guidelines of the American Academy of Orofacial Pain (22), 
although espousing a biopsychosocial approach, also include the diagnosis of psychogenic pain.

The purported clinical features of 'psychogenic pain' include nonanatomical, often bilateral distribution (27). The pain is thought to be an amplification of normal sensations (30) or of an intensity greater than what would normally be expected on the basis of clinical findings $(27,29)$. It may be continuous with little fluctuation in intensity, spread from one site to another and recur after successful treatment (27). Many of these characteristics of pain have also been associated with cases of clear organic pathology. More importantly, our growing understanding of the peripheral and central neural mechanisms involved in pain also can account for many of these features (31-36). For example, spontaneous pain (ie, in the absence of a known trigger), pain in response to innocuous stimuli (allodynia) and heightened pain in response to a normally painful stimulus (hyperalgesia) are well documented features of central sensitization that arise following injury to the peripheral or central nervous systems (37-39). There is a fascinating literature on the expression of novel receptive fields (40) and the expansion of existing receptive fields $(41,42)$ in response to alterations in the flow of afferent input. This literature provides a neurophysiological basis for the spread of pain to distant, previously nonpainful regions (39) and a rationale for why treatments applied at one site may relieve pain at another (43).

Remnants of specificity theory underlie the thinking that attributes these features of 'psychogenic pain' to psychopathology, namely, the idea that any deviation from a direct relationship between injury and pain is evidence of a psychogenic and, by implication, psychopathological cause. However, the link between pain and injury is variable, and this variability is not an indication of psychopathology but rather can be explained by the wealth of basic science and clinical data spawned by the gate-control theory of pain (1).

In addition to clinical guidelines and texts, there is considerable evidence that specificity theory pervades orofacial pain management. Dentists overdiagnose psychopathology, while correlations between dentists' clinical assessments and scores on validated measures of psychological distress are, at best, low (44). In one study, $20 \%$ of dentists surveyed indicated their belief that orofacial pain is most commonly caused by psychogenic factors second only to neurogenic factors (45). This tendency to view orofacial pain as psychogenic is illustrated in recent case studies that share several features. The patient presents with pain and a history of multiple surgical interventions or injury. This history is disregarded as contributory and instead psychogenic pain or painprone disorder is diagnosed with the formulation that these unfortunate people 'need' their pain $(46,47)$. A number of treatments follow. In one case (46), because the woman was said to need her pain, she was offered treatment along with a promise not to cure! In other cases (47), pain relief is obtained through psychological techniques such as hypnosis and relaxation. Positive response to these treatments is taken as confirmation of the psychogenic cause of the pain, while partial or poor response is taken as confirmation of the pa- tient's psychopathological need to have pain $(46,47)$. Exacerbation or recurrence of pain following successful treatment leads to a reinterpretation of the initial pain relief as a placebo response, which is then taken as further evidence that the pain has a psychogenic cause $(46,47)$. It is most unfortunate in these cases that evidence for a psychogenic cause is not presented, a history of repeated tissue damage is ignored and response to a psychological pain management strategy is taken as evidence of a psychogenic cause. When patients such as these are examined more carefully, psychogenesis of pain is ruled out and appropriate treatment alleviates the pain (48).

The widespread dichotomization of pain into psychogenic versus organic cause is not limited to case reports. Uncontrolled studies have found increased somatization and depression in groups of patients with orofacial pain $(30,49,50)$. Although such data are often taken as evidence that orofacial pain is caused by psychopathology, the lack of a comparison group and prospective data makes this interpretation inappropriate. Comparisons between patients with orofacial pain and pain-free controls have found increased levels of psychopathology among those with chronic pain (51-54). This has been interpreted as evidence that psychopathology and/or personality factors cause orofacial pain, but these studies are not designed to allow inferences regarding causality. Furthermore, the data are consistent with studies comparing most populations with chronic illness with healthy controls and can, at best, only shed light on the psychological consequences of living with a chronic illness (55). Psychological distress is a normal consequence of chronic illness and should not be confused with psychopathology. We have been unable to find evidence that unequivocally supports the idea that orofacial pain is caused by psychopathology or psychiatric illness.

Another approach has been to compare 'psychogenic' orofacial pain patients with those who have pain associated with demonstrated organic pathology. Differences between the groups on several measures of psychopathology have not been found, including constructs such as parental bonding, which has been proposed to underlie psychogenic symptomatology (56). In one study (57), a self-report measure classified a greater proportion of the 'psychogenic' patients as psychiatric 'cases'. However, the proportion of patients in the 'psychogenic' and 'organic' pain groups who met the criteria for a current or past mental disorder did not differ significantly. Taken together, these studies suggest that psychopathology does not differ between orofacial pain patients with and patients without demonstrable organic pathology and have led to the conclusion that "the prevailing hypotheses overemphasize the role of psychological illness" (56).

Nonetheless, there is a high comorbidity of psychological distress, especially depression and anxiety, and orofacial pain. Importantly, however, these patients are not different from those with other chronic pain disorders $(25,58-60)$, and there is even evidence that they may report lower levels of distress than other groups of chronic pain patients $(58,61,62)$. There are several possible explanations for the association between pain and psychological distress. Specifically, it may 
be a cause or consequence of pain, or both may share a common mechanism $(20,63)$. The possibility that psychological distress can exacerbate pain is predicted by the gate-control theory (1) and is widely accepted and, therefore, will not be explored here. Rather, our interest lies in the question of the underlying causal relationship (if one exists) between psychopathology and pain. Data that conclusively show that psychopathology causes chronic orofacial pain are not available (64). On the contrary, one prospective study that followed general medical practice patients for three years found that neither intensity nor chronicity of depressive symptomatology at baseline predicted onset of temporomandibular disorder three years later (65).

There is evidence that psychological distress is a normal consequence for patients with chronic orofacial pain. Successful management of orofacial pain, often with nonpsychological interventions, is associated with decreased levels of affective disturbance, somatization and abnormal illness behaviour that is maintained at follow-ups ranging from five months to three years $(58,66,67)$. Interestingly, in these patients, subsequent increases or recurrences of pain are associated with increased levels of psychological distress (67). These changes are seen even with successful surgical management of atypical facial pain, which, by definition, is a supposed psychogenic pain disorder (67). It is difficult to conceptualize why a stable personality trait such as somatization would fluctuate with level of pain and be reduced by nonpsychological treatment, unless elevations on scores of somatization are a consequence rather than a cause of pain (68).

Another aspect of the characterization of orofacial pain patients deserves mention, specifically the idea that positive response to placebo and negative response to active drug are evidence of a psychopathological cause of orofacial pain. In samples of patients with myofascial pain dysfunction syndrome, a supposed nonorganic subtype of temporomandibular disorder, $52 \%$ to $64 \%$ reported symptom improvement in response to placebo $(69,70)$. This has been taken as evidence for the psychopathological basis of this disorder. On the other hand, lack of response to active treatment is also taken as evidence of mental illness (namely a psychopathological need to have pain that prevents improvement $[46,47])$, while response to active treatment greater than that of placebo is described as unexpected and is explained away as an artefact (71). The possibility that analgesics might benefit patients with psychogenic pain to a comparable degree as those with organic pain is not considered (71). This reasoning implies that medically unexplained pain does not really hurt. It also ignores work suggesting that a placebo response is not an indication of psychopathology $(56,72)$ and that pain treatments rarely are associated with complete pain relief (73). Patients with medically unexplained orofacial pain are put in an untenable position. Both treatment success and failure, whether active or placebo, are attributed to mental illness. It is not surprising that these patients feel stigmatized and misunderstood $(74,75)$ - they are.

It is clear that the dichotomization of chronic orofacial pain into organic and psychopathological cause persists, de- spite a lack of empirical or theoretical basis. This has serious clinical implications. Patients with medically unexplained symptoms, the majority of whom have been told that their pain is imaginary, are less likely to receive analgesic medication (76). In addition, this type of thinking may underlie the often negative attributes ascribed to patients with supposed psychogenic pain, especially atypical facial pain. These patients are described as angry, hostile, demanding and having little insight. These pejorative descriptors are used without citation to supporting evidence. Given these attitudes among health care workers, it is no wonder that these patients often feel stigmatized after being told that there is 'no reason' they should have pain or that the pain is imaginary $(74,75)$. As a result, patients may seek further consultation in an effort to find a practitioner who will believe them (77). However, even this very understandable response is taken as further evidence of a psychogenic basis for the pain (46), despite the well known selection bias that operates in the referral of patients to chronic pain clinics (20). Other patients may respond by trying to prove that they are indeed in pain (77). Attempting to prove to a dualistic thinking practitioner that one's pain is real is then taken as further evidence that one is indeed suffering from psychopathology, specifically hypochondriasis or abnormal illness behaviour (78). The burden of having to prove that one is really in pain also impedes recovery. To become well under these circumstances is further evidence that one was not ill to begin with (79).

\section{CONCLUSIONS}

Ron Melzack's theoretical and empirical contributions have revolutionized pain research and therapy. As a result of his work, we have come to understand the pivotal role that emotions and cognitions play in the generation, exacerbation and alleviation of pain. Most importantly, Ron's work has normalized the role of these factors in pain. As such, it is not necessary to invoke psychopathological mechanisms to explain why emotional factors play a role in a particular patient's pain. This is not to deny that pain and psychopathology present as comorbid conditions; they do and, in all such cases, both require appropriate care (80). More common are patients who report pain for which organic pathology has not been identified. Ron and many other careful researchers have shown that the variable link between pain and organic damage is not a consequence of psychopathology. However, we have reviewed evidence to suggest that these unfortunate patients often remain victims of facile, dualistic thinking that readily psychopathologizes their pain. Does mental illness, in and of itself, cause pain? Logically, we are unable to prove that it does not. The challenge remains for its proponents to provide the empirical evidence that mental illness causes pain and to specify the mechanisms by which it is generated. We believe that medically unexplained pain is not a symptom of a psychological disorder and that it is time to abandon the thinking that separates mind and body. Much of the attribution of 'nonorganic' pain to psychopathology is the result of misinformation and over-reliance on outmoded Cartesian concepts of pain. It is well documented that most health pro- 
fessionals do not receive adequate training in pain theory or management $(81,82)$.

The solution to needless pain is education in all its facets ... If we can pursue these goals together - as scientists and therapists, as members of the full range of the scientific and health professions - we can hope to meet the goal we all strive for: to help our fellow human beings who suffer needless pain. (83)

ACKNOWLEDGMENTS: This work was supported by grants MOP-37845 and MCT-38144 from the Medical Research Council of Canada (MRC), grant NS35480 from the National Institutes of Health, an MRC Fellowship Award to Dr Gagliese and an MRC Scientist Award to Dr Katz.

\section{REFERENCES}

1. Melzack R, Wall PD. The Challenge of Pain. London: Penguin Books, 1988.

2. Melzack R. The perception of pain. Sci Am 1961;204:41-9.

3. Melzack R, Wall PD. Pain mechanisms: a new theory. Science 1965;150:971-9.

4. Engel GL. The need for a new medical model: a challenge for biomedicine. Science 1977;196:129-36.

5. Benini A, DeLeo JA. Rene Descartes' physiology of pain. Spine 1999;24:2115-9.

6. Melzack R. Gate control theory: On the evolution of pain concepts. Pain Forum 1996;5:128-38.

7. Melzack R, Casey KL. Sensory, motivational and central control determinants of pain: A new conceptual model. In: Kenshalo D, ed. The Skin Senses. Springfield: Charles C Thomas, 1968:423-39.

8. Melzack R, Loeser JD. Phantom body pain in paraplegics: evidence for a central "pattern generating mechanism" for pain. Pain 1978;4:195-210.

9. Melzack R. Phantom limbs and the concept of a neuromatrix. Trends Neurosci 1990;13:88-92.

10. Melzack R. From the gate to the neuromatrix. Pain 1999;(Suppl 6):S121-6.

11. Wolff BB. Gate control theory and the brain. Pain Forum 1996;5:147-9.

12. Engel GL. 'Psychogenic' pain and the pain-prone patient. Am J Med 1959;26:899-918.

13. Stengel E. Pain and the psychiatrist. Br J Psychiatry 1965;111:795-802.

14. Szasz TS. Pain and Pleasure: A Study of Bodily Feelings. New York: Basic Books, 1957.

15. Gamsa A. The role of psychological factors in chronic pain. I. A half century of study. Pain 1994;57:5-15.

16. Novy DM, Nelson DV, Francis DJ, Turk DC. Perspectives of chronic pain: an evaluative comparison of restrictive and comprehensive models. Psychol Bull 1995;118:238-47.

17. Bogduk N. Who let the cat out of the bag. Pain Res Manage 2000;5:10-11.

18. Katz J. Psychophysiological contributions to phantom limbs. Can J Psychiatry 1992;37:282-98.

19. Engel GL. "Psychogenic" pain and the pain-prone patient. In: Grzesiak RC, Ciccone DS, eds. Psychological Vulnerability to Chronic Pain. New York: Springer, 1994:179-221.

20. Merskey H. Psychiatry and chronic pain. Can J Psychiatry 1989;34:329-36.

21. Szasz TS. A psychiatric perspective on pain and its control. In: Hart FD, ed. The Treatment of Chronic Pain. Lancaster: Medical and Technical Publishing Co Ltd, 1974:39-61.

22. American Academy of Orofacial Pain. Orofacial Pain: Guidelines for Assessment, Diagnosis and Management. Chicago: Quintessence Publishing, 1996.
23. Merskey H, Bogduk N, eds. Classification of Chronic Pain, 2nd edn. Seattle: IASP Press, 1994.

24. Marbach JJ, Raphael KG. Future directions in the treatment of chronic musculoskeletal facial pain: the role of evidence-based care. Oral Surg Oral Med Oral Pathol Oral Radiol Endod 1997;83:170-6.

25. Rudy TE, Turk DC, Zaki HS, Curtin HD. An empirical taxometric alternative to traditional classification of temporomandibular disorders. Pain 1989;36:311-20.

26. Sessle BJ. Oral-facial pain: old puzzles, new postulates. Int Dent J 1978;28:28-42.

27. Klineberg I. Craniomandibular disorders and orofacial pain: Diagnosis and management. Oxford: Butterworth-Heinemann Ltd, 1991.

28. Sharav Y. Orofacial pain. In: Wall PD, Melzack R, eds. Textbook of Pain. Edinburgh: Churchill Livingstone, 1999:711-38.

29. van der Bij1 P. Psychogenic pain in dentistry. Compendium $1995 ; 16: 46,48,50-3$.

30. Eli I, Baht R, Littner MM, Kleinhauz M. Detection of psychopathologic trends in glossodynia patients. Psychosom Med 1994;56:389-94.

31. Devor M, Basbaum AI, Bennett GJ, et al. Group report: Mechanisms of neuropathic pain following peripheral injury. In: Basbaum AI, Besson J-M, eds. Towards a New Pharmacotherapy of Pain. New York: John Wiley \& Sons, 1991:417-40.

32. Coderre TJ, Katz J, Vaccarino AL, Melzack R. Contribution of central neuroplasticity to pathological pain: Review of clinical and experimental evidence. Pain 1993;52:259-85.

33. Doubell TP, Mannion RJ, Woolf CJ. The dorsal horn: state-dependent sensory processing, plasticity and the generation of pain. In: Wall PD, Melzack R, eds. Textbook of Pain, 4th edn. Edinburgh: Churchill Livingstone, 1999:165-81.

34. Sessle BJ. Neural mechanisms and pathways in craniofacial pain. Can J Neurol Sci 1999;26(Suppl 3):S7-11.

35. Ren K, Dubner R. Central nervous system plasticity and persistent pain. J Orofac Pain 1999;13:155-63.

36. Koltzenburg M, Wall PD, McMahon SB. Does the right side know what the left is doing? Trends Neurosci 1999;22:122-7.

37. Coderre TJ, Katz J. Peripheral and central hyperexcitability: differential signs and symptoms in persistent pain. Behav Brain Sci 1997;20:404-19.

38. Devor M, Seltzer Z. Pathophysiology of damaged nerves in relation to chronic pain. In: Wall PD, Melzack R, eds. Textbook of Pain, 4th edn. Edinburgh: Churchill Livingstone, 1999:129-64.

39. Woolf CJ. Central mechanisms of acute pain. In: Bond MR, Charlton JE, Woolf CJ, eds. Proceedings of the Vth World Congress on Pain. Amsterdam: Elsevier, 1991:25-34.

40. Dostrovsky JO, Millar J, Wall PD. The immediate shift of afferent drive to dorsal column nucleus cells following deafferentation: a comparison of acute and chronic deafferentation in gracile nucleus and spinal cord. Exp Neurol 1976;52:480-95.

41. Woolf CJ. Evidence for a central component of post-injury pain hypersensitivity. Nature 1983;306:686-8.

42. Devor M, Wall PD. Plasticity in the spinal cord sensory map following peripheral nerve injury in rats. J Neurosci 1981;1:679-84.

43. Gracely RH, Lynch SA, Bennett GJ. Painful neuropathy: altered central processing maintained dynamically by peripheral input. Pain 1992;51:175-94.

44. Oakley ME, McCreary CP, Flack VF, Clark GT, Solberg WK, Pullinger AG. Dentists' ability to detect psychological problems in patients with temporomandibular disorders and chronic pain. J Am Dent Assoc 1989;118:727-30.

45. Dahlstrom L, Lindvall AM, Milthon R, Widmark G. Management of chronic orofacial pain: attitudes among patients and dentists in a Swedish county. Acta Odontol Scand 1997;55:181-5.

46. Vassos DM, Azim HFA. An interdisciplinary approach to treating psychogenic pain in the dental implant patient. Gen Dent 1991;39:280-2.

47. Golan HP. The use of hypnosis in the treatment of psychogenic oral pain. Am J Clin Hypn 1997;40:89-96. 
48. Lee STS. Psychogenic pain or lingual tonsillitis? Br J Hosp Med 1991;45:314-5.

49. Moore DS, Nally FF. Atypical facial pain: an analysis of 100 patients with discussion. J Can Dent Assoc 1975;41:396-401.

50. Nally FF, Moore DS. Psychogenic, diagnostic and therapeutic aspects of temporomandibular joint pain: an analysis of 232 patients with discussion. J Can Dent Assoc 1975;41:403-6.

51. Trikkas G, Nikolatou O, Samara C, Bazopoulou-Kyrkanidou E, Rabavilas AD, Christodoulou GN. Glossodynia: personality characteristics and psychopathology. Psychother Psychosom 1996;65:163-8.

52. Bogetto F, Maina G, Ferro G, Carbone M, Gandolfo S. Psychiatric comorbidity in patients with burning mouth syndrome. Psychosom Med 1998;60:378-85.

53. Eli I, Kleinhauz M, Baht R, Littner M. Antecedents of burning mouth syndrome (glossodynia) - recent life events vs. psychopathologic aspects. J Dent Res 1994;73:567-72.

54. Miyaoka H, Kamijima K, Katayama Y, Ebihara T, Nagai T. A psychiatric appraisal of "glossodynia". Psychosomatics 1996;37:346-8.

55. Taylor SE. Health Psychology, 4th edn. Boston: McGraw Hill, 1999.

56. Salter M, Brooke RI, Merskey H, Fichter GF, Kapusianyk DH. Is the temporo-mandibular pain and dysfunction syndrome a disorder of the mind? Pain 1983;17:151-66.

57. Browning S, Hislop S, Scully C, Shirlaw P. The association between burning mouth syndrome and psychosocial disorders. Oral Surg Oral Med Oral Pathol 1987;64:171-4.

58. Schnurr RF, Brooke RI, Rollman GB. Psychosocial correlates of temporomandibular joint pain and dysfunction. Pain 1990;42:153-65.

59. Graff-Radford SB, Solberg WK. Is atypical odontalgia a psychological problem? Oral Surg Oral Med Oral Pathol 1993;75:57982.

60. Grushka M, Sessle BJ, Miller R. Pain and personality profiles in burning mouth syndrome. Pain 1987;28:155-67.

61. Marbach JJ, Lund P. Depression, anhedonia and anxiety in temporomandibular joint and other facial pain syndromes. Pain 1981;11:73-84.

62. Merskey H, Lau CL, Russell ES, et al. Screening for psychiatric morbidity. The pattern of psychological illness and premorbid characteristics in four chronic pain populations. Pain 1987;30:141-57.

63. Robinson ME, Riley JL, eds. The Role of Emotion in Pain. New York: Guilford Press, 1999.

64. Craig K. Emotions and psychobiology. In: Wall PD, Melzack R, eds. Textbook of Pain. Edinburgh: Churchill Livingstone, 1999:331-44.

65. Von Korff M, Le Resche L, Dworkin SF. First onset of common pain symptoms: a prospective study of depression as a risk factor. Pain $1993 ; 55: 251-8$
66. Feinmann C. Psychogenic facial pain: presentation and treatment. J Psychosom Res 1983;27:403-10.

67. Zakrzewska JM, Jassim S, Bulman JS. A prospective, longitudinal study on patients with trigeminal neuralgia who underwent radiofrequency thermocoagulation of the Gasserian ganglion. Pain 1999;79:51-8.

68. Sternbach RA, Timmermans G. Personality changes associated with reduction of pain. Pain 1975;1:177-81.

69. Goodman P, Greene CS, Laskin DM. Response of patients with myofascial pain-dysfunction syndrome to mock equilibration. J Am Dent Assoc 1976;92:755-8.

70. Laskin DM, Greene CS. Influence of the doctor-patient relationship on placebo therapy for patients with myofascial pain-dysfunction (MPD) syndrome. J Am Dent Assoc 1972;85:892-4.

71. Fishbain DA, Cutler RB, Rosomoff HL, Rosomoff RS. Do antidepressants have an analgesic effect in psychogenic pain and somatoform pain disorder? A meta-analysis. Psychosom Med 1998;60:503-9.

72. Wall PD. The placebo and the placebo response. In: Wall PD, Melzack R, eds. Textbook of Pain. Edinburgh: Churchill Livingstone, 1999:1419-30.

73. Wall PD, Melzack R, eds. Textbook of Pain. Edinburgh: Churchill Livingstone, 1999.

74. Lennon MC, Link BG, Marbach JJ, Dohrenwend BP. The stigma of chronic facial pain and its impact on social relationships. Soc Probl 1989;36:117-33.

75. Marbach JJ, Lennon MC, Link BG, Dohrenwend BP. Losing face: sources of stigma as perceived by chronic facial pain patients. J Behav Med 1990;13:583-604

76. Kouyanou K, Pither CE, Rabe-Hesketh S, Wessely S. A comparative study of iatrogenesis, medication abuse, and psychiatric morbidity in chronic pain patients with and without medically explained symptoms. Pain 1998;76:417-26.

77. Glover L, Jones S, Harrison S. Psychological issues in dentistry. In: Feinmann C, ed. The Mouth, the Face, and the Mind. Oxford: Oxford University Press, 1999:103-14.

78. Pilowsky I. Abnormal illness behaviour: a 25th anniversary review. Aust NZ J Psychiatry 1994;28:566-73.

79. Hadler NM. If you have to prove you are ill, you can't get well. The object lesson of fibromyalgia. Spine 1996;21:2397-400.

80. Veilleux S, Melzack R. Pain in psychotic patients. Exp Neurol 1976;52:535-43.

81. Pilowsky I. An outline curriculum on pain for medical schools. Pain 1988:33:1-2.

82. Poyhia R, Kalso E. Pain related undergraduate teaching in medical faculties in Finland. Pain 1999;79:121-5.

83. Melzack R. The tragedy of needless pain: a call for social action. In: Dubner R, Gebhart GF, Bond MR, eds. Proceedings of the Vth World Congress of Pain. Amsterdam: Elsevier, 1988:1-11. 


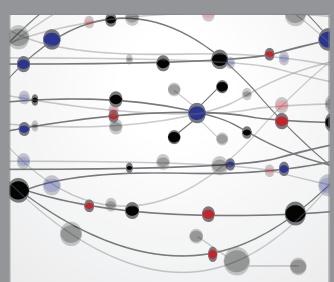

The Scientific World Journal
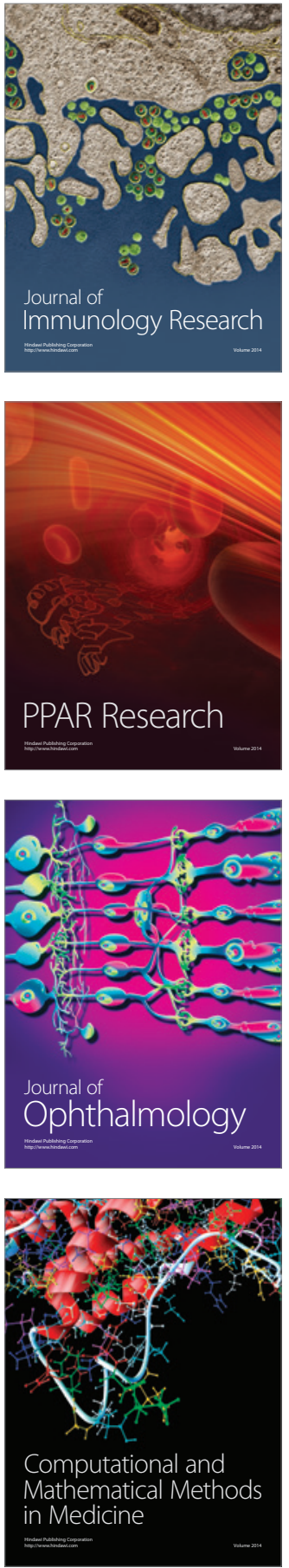

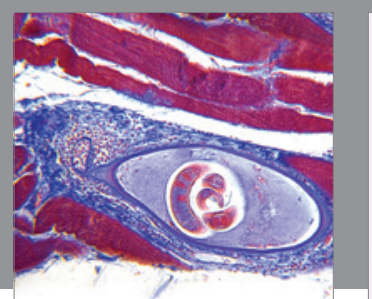

Gastroenterology Research and Practice

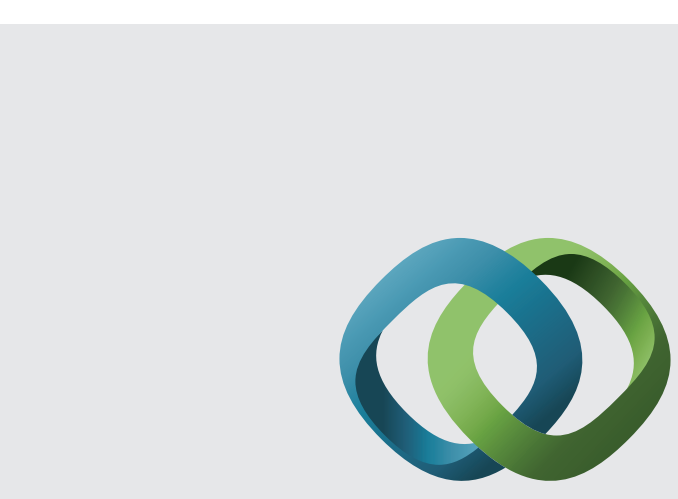

\section{Hindawi}

Submit your manuscripts at

http://www.hindawi.com
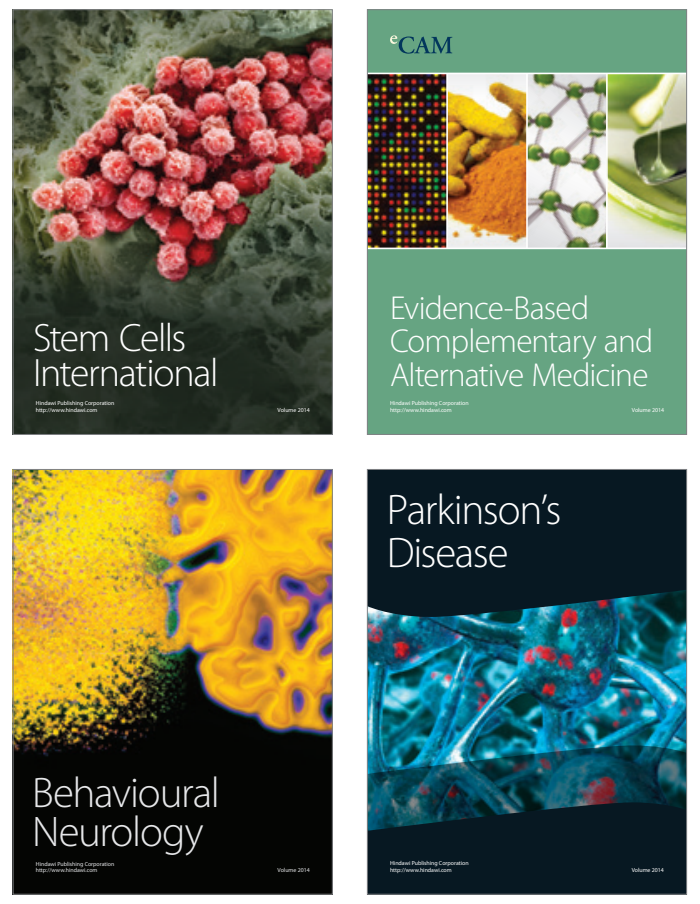
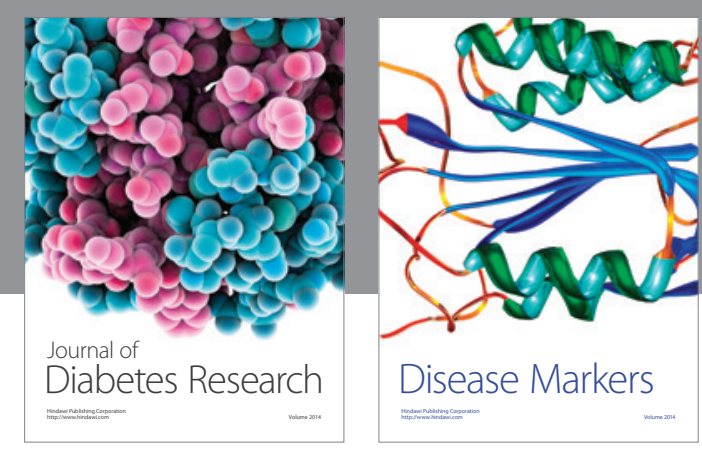

Disease Markers
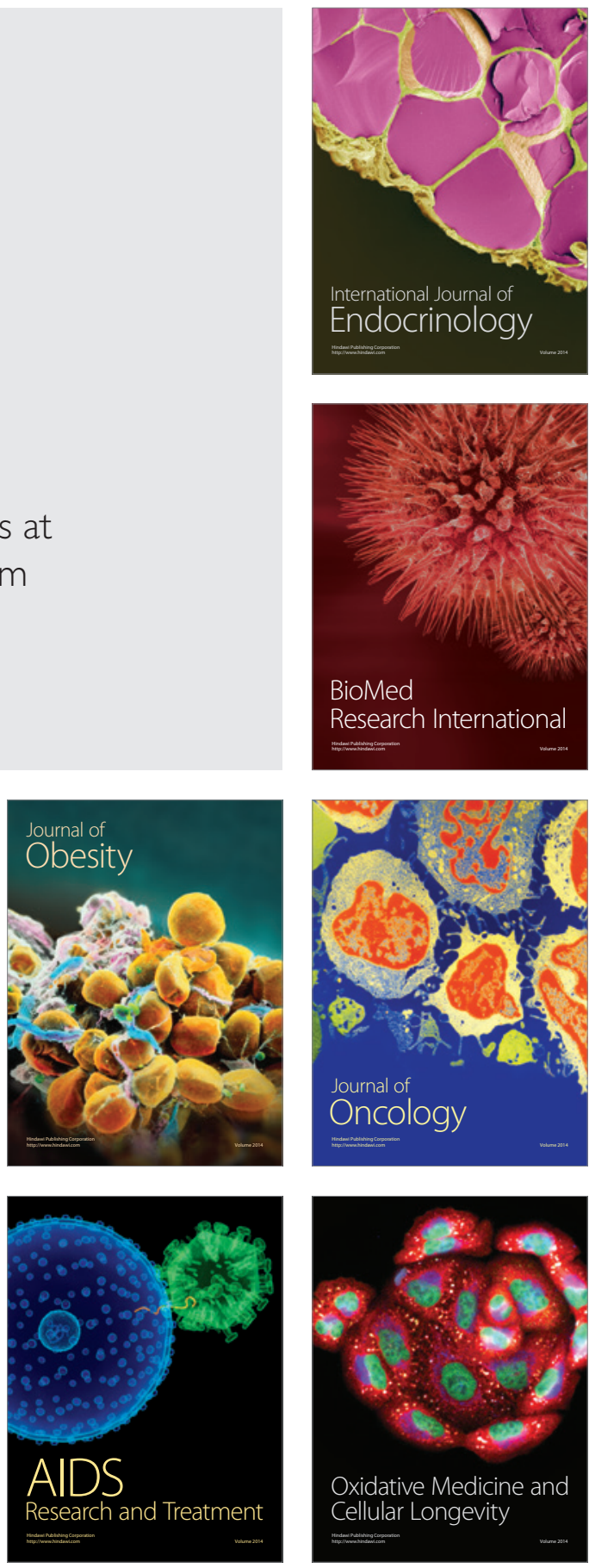